\title{
Unjust pains: the impact of Covid 19 on children in prison
}

\section{Tim Bateman}

This is the peer reviewed, final draft, of the article accepted for publication, on 9 September 2020, in the Journal of Children's Services: DOI $10.1108 / \mathrm{JCS}-07-2020-0045$

This version may be used for non-commercial purposes.

Key words:

Child imprisonment; Covid 19; lockdown; pains of imprisonment; children in custody; response to pandemic 


\section{Structured abstract}

Purpose

To consider the implications of the Covid 19 pandemic for the treatment of children in penal custody.

\section{Design/methodology/approach}

The paper is a viewpoint piece that analyses the consequences of the Covid 19 pandemic for children in custody, drawing on published information where available.

\section{Findings}

The paper argues that imprisoned children are an extremely vulnerable group whose experience of incarceration exacerbates that vulnerability at the best of times. Responses to Covid 19 are particularly painful for children those settings and the consequences are manifestly unjust.

\section{Originality}

The paper provides an early attempt to consider the impact of Covid 19 on children in prison. 


\section{Introduction: outside, looking in}

Courts in England and Wales, when sentencing children convicted of an offence, are enjoined to weigh a range of competing factors that have evolved over time to reflect the distinct status of defendants below the age of 18 years. The starting point, however, as with adults, remains the imposition of a punishment proportionate to the seriousness of the offending (Sentencing Council, 2017). The principle of proportionality was enshrined in domestic legislation by the Criminal Justice Act 1991 (Ashworth, 2017) as a mechanism purporting to limit the severity of court disposals according to the culpability of the individual defendant to ensure 'just deserts' (Lacey and Pickard, 2015). The main determinant of youth sentencing, albeit mediated by other considerations such as the welfare of the children and the prevention of reoffending, is accordingly the infliction of, what might be called, a ‘just measure of pain' (Ignatieff, 1989).

Deprivation of liberty represents the highest level of punishment which the state can impose in response to a child's offending. For that reason, the UN Convention on the Rights of the Child requires that custody must be used only as a 'measure of last resort' (United Nations, 1989, Article 37), although whether this obligation is manifested is practice is a separate question (see, for instance, Standing Committee for Youth Justice, 2020). From a legal perspective, the punitive quality of incarceration derives not from the nature of the child's treatment within the custodial facility, but rather, as with lower-level, non-custodial, penalties, from the restriction on liberty. It is, in theory at least, the loss of freedom which constitutes the punishment and, for this reason, statutory guidance to the judiciary requires that the length of sentence 'must be the shortest commensurate with the seriousness of the offence' (Sentencing Council, 2017, p29). The UN Convention, moreover, obliges States to ensure that no child is subject to 'cruel, inhuman or degrading treatment or punishment' and that:

'[e]very child deprived of their liberty shall be treated with humanity and respect for the inherent dignity of the human person, and in a manner which takes into account the needs of persons of his or her age' (United Nations, 1989, Article 37).

The requirement for humane treatment of imprisoned children is, at least in part, a recognition that deprivation of liberty is, in and of itself, a painful experience. More than half a century ago, in his classic study of adult prisoners in America, Gresham M Sykes (1958/ 2007) demonstrated that the 'pains of imprisonment' were tangible and inevitable. They included loss of freedom, restricted access to material goods and services, reduced autonomy and a diminished sense of safety and security. In reality, of course, the treatment of children within the custodial estate adds 
considerably to the pains of imprisonment - an issue which receives further attention below. As Liebling (2011: 530) contends, confinement is intrinsically painful irrespective of the nature of the custodial regime, but there are 'differences that matter', which serve to either exacerbate or ameliorate the extent of suffering.

For current purposes, it is worth pausing to reflect on the extent of distress caused purely by restricting freedom. It has been observed by some that, from the 23 March 2020, the general public has been given a taste of how difficult restrictions on liberty can be (see for instance, Little, 2020a; Independent Advisory Panel on Deaths in Custody, 2020). The experience of 'lockdown', whereby large sections of the population have been confined to their homes for lengthy periods, denied access to friends and relatives other than those in the immediate household, and had their social interactions and leisure activities severely circumscribed, has been extremely stressful for many, with the effects being felt deeply by both children and adults. Social deprivation is, however, likely to have a disproportionate impact on adolescents, with far-reaching consequences for their longer-term wellbeing and mental health, albeit that these might be mitigated, to a degree, by access to social media and other forms of digital interaction. As Orben and colleagues (2020, p634) have shown, contact with others is a basic human necessity, 'analogous to other fundamental needs such as food consumption or sleep', but physical distancing is particularly harmful to teenagers because they are:

'at a unique period in their lives when the social environment is important for crucial functions in brain development, self-concept construction, and mental health' (Orben et al, 2020, p638).

As Little (2020a) acknowledges, however, drawing a parallel between lockdown and imprisonment is misleading for at least three reasons. First, the statutory expectations notwithstanding, the experiences of children in custody in 'normal' times, is incomparably more injurious than those of children subject to the worst excesses of lockdown. On the one hand, restrictions on liberty associated with incarceration are at a qualitatively different scale: the autonomy of children in lockdown, their choice of activities, access to material goods, and sense of security are all considerably less restricted than they are for those who have been removed from the community. At the same time, the notion that the punishment of confinement consists purely in deprivation of liberty is, as described below, fanciful.

Second, while the principle of proportionality is bolstered by a gloss of impartiality and equality of treatment, the veneer is extremely thin and quickly evaporates when exposed to the glare of implementation. 'Just deserts' is, Lacey and Pickard (2015) suggest, a 'chimera', being a product of political and social construction rather than 
a pre-existing natural relationship. If, as suggested above, teenagers are the most adversely affected by lockdown restrictions, it follows that similar developmental considerations apply equally to those sentenced to custody. The fact that children are at a key point of transition, where development can be promoted or stunted, exacerbates the pains of confinement by comparison with adults. Locking up children can thus be considered disproportionate because of the particular consequences of the loss of liberty at a young age (Gooch, 2016).

Imprisonment is, moreover, largely reserved for a particular demographic of children, those whose backgrounds are marked by poverty and deprivation and, frequently, ethnic minority status (Yates, 2010; Kingston and Webster, 2016; Webster, 2015). For such reasons, the use of child custody in England and Wales has been characterised as 'punishing disadvantage' (Jacobson et al, 2010). The starting point for children deprived of their liberty through the justice system is accordingly substantially different to that of the general child population impacted by responses to corona virus and their pains are correspondingly greater. Tellingly, in some contexts, the former report that their experience of custody as punitive can be tempered by a perception that their basic needs, which had been neglected in the community, are now being met (McAlister and Carr, 2014). Conversely, the "/oss of childhood" which, as Gooch (2016: 3) persuasively argues, is the most pernicious pain of children imprisonment, is likely to be felt more keenly by those whose futures are, in any event, tightly constrained by socio-economic circumstance.

Finally, the response to the Covid 19 pandemic has ensured that there is an additional 'lockdown penalty' for those within the custodial estate. If the liberties of children in the community have been curtailed to an extent that might be legitimately considered harmful, the new restrictions on incarcerated children have been markedly more severe.

\section{The 'normal' state of the estate}

Children remanded or sentenced to custody in England and Wales are held in one of three types of establishment which in combination constitute the 'children's secure estate'. Young offender institutions (YOIs), which accommodate boys aged $15-17$ years of age, bear a marked similarity to adult prisons and are generally based in premises that have, at some time in the past, fulfilled that function. They are considerably larger than other secure facilities for children and have a corresponding lower staff-to-child ratio. Secure training centres (STCs) are privately managed custodial facilities for children aged 12-17 years, including boys aged 1517 deemed too vulnerable to be placed in YOls. They are not as large as YOls and have a correspondingly higher staff-to-child ratio. By contrast, secure children's 
homes (SCHs) are child care establishments that can accommodate children detained on welfare grounds, under section 25 of the Children Act 1989, as well those subject to custodial orders. They accommodate children aged 10-17 assessed as particularly vulnerable. SCHs are substantially smaller than other forms of provision and also enjoy, by some margin, the highest staff-to-child ratio. Crucially, unlike other custodial settings, SCHs benefit from having a care-based rather than correctional ethos (Bateman, 2016). For such reasons, there is a growing consensus that STCs and YOIs are not fit for the purpose of accommodating vulnerable children (Taylor, 2016; Wood et al, 2017) and the government has accepted in principle that such establishments should be abolished (Ministry of Justice, 2016), but little progress has been made towards that objective (Bateman, 2020).

The number of children in custody has fallen dramatically in recent years, from 3,006 in May 2008 to 614 in May 2020 (Youth Custody Service, 2020). Nonetheless, despite widespread acknowledgement that SCHs are the only current form of provision capable of addressing the needs of vulnerable children (see for instance, End Child Imprisonment, 2019), any expectations that the decline in the custodial population would provide an opportunity to place a higher proportion of those detained in more child-friendly facilities have been dashed. At May 2020, just 9\% of children deprived of their liberty though the youth justice system were accommodated in SCHs (Youth Custody Service, 2020). The proportion of children imprisoned in YOIs has conversely risen since the government's commitment to abolish those establishments, from 72\% in April 2016 to 76\% in May 2020 (Bateman, 2020). Given that no rationale has been given for this pattern of placement, one is left to surmise that 'cost-per-child place is a dominant driving force' (Little, 2020b, p1).

It is evident that as the imprisoned population has shrunk, conditions within custodial settings have deteriorated and the experiences of children within them, have become demonstrably worse, from an already shameful baseline. In 2018/19, more than one-in-three children (35\%) in YOIs and STCs reported that they had felt unsafe at some point during their stay (Taflan and Jalil, 2020). This subjective experience reflects a harsh objective reality. The use of physical restraint, levels of assault, the prevalence of self-harm and episodes of single separation, relative to the numbers of children incarcerated, have each shown alarming rises over the past seven years. For instance, in 2012 there were, on average, 25.1 episodes of restraint per 100 children in custody; by 2019 there were 46.6. The equivalent figures for self-harm were, over the same period, 5.1 and 13.7 respectively (Ministry of Justice / Youth Justice Board, 2020a). 
Current regulations allow the deliberate infliction of pain during the course of restraining a child in YOIs and STCS - but not SCHs. A recently published review of restraint in those settings confirmed that:

'There is an unacceptable level of violence in YOI and STC [sic] .... Many of the children have led traumatic lives and have been subjected to abuse.... This is compounded by putting them in, what can be, a frightening and dangerous environment in which they can find themselves assaulted by their peers and physically restrained. This is made worse when adults deliberately inflict pain in circumstances in which it cannot be justified' (Taylor, 2020, p18).

The pains of imprisonment thus too often include physical pain, in this case deliberately inflicted on children with state approval, a circumstance which the Independent Inquiry into Child Sexual Abuse characterises as 'a form of child abuse' (Jay et al, 2019, pvi).

The psychological pains associated with, what is officially known as, single separation, a process whereby children are removed from the standard regime and association with their peers, are also considerable. A recent thematic inspection of practice in YOls concluded that children in isolation were prevented from accessing the 'very basics of everyday life' such as daily showers (HM Inspectorate of Prisons, 2019: 5); in the worst cases children were locked in their cells for all but 15 minutes in 24 hours, in effect subject to solitary confinement - defined as 'confinement... for 22 hours or more a day without meaningful human contact' - which, in the case of children, is prohibited by international human rights standards (United Nations, 2015: Rule 44). But even where they are not subject to single separation, children in YOIs have limited time out of their cells: around one in five are typically locked up during the day when they should be in education (HM Chief Inspector of Prisons, 2019).

In STCs and YOIs, basic necessities of everyday life are not readily accessible. During $2018 / 19$, just over one third of children (37\%) said that they had enough to eat and fewer still rated the quality of food as good. Less than half considered that the temperature of their room/ cell was comfortable or that the environment was quiet enough to sleep at night (43\% and 49\% respectively) (Taflan and Jalil, 2020). In the same year, almost three quarters of children entering custody were assessed as having mental health concerns (71\%) Ministry of Justice / Youth Justice Board (2020b) but just $45 \%$ reported that mental health support was easily available (Taflan and Jalil, 2020). 
The dramatic worsening of conditions for imprisoned children implies that, if ever such confinement might have been rationalised as a proportionate response to their offending - and as noted above there are grounds for questioning that assumption, a justification grounded in just-deserts is no longer tenable. The calls by campaigning organisations, such as Article 39 and the National Association for Youth Justice, to abolish penal custody for children have, as a consequence, become increasingly persuasive (End Child Imprisonment, 2019; Bateman, 2016).

\section{It's gone viral}

If the pains of imprisonment for incarcerated children at the best of times outweigh, by some margin, the pains of lockdown at the worst of times, the response by the authorities to the Covid 19 pandemic has triggered a substantial realignment of the goalposts, exacerbating the harms experienced by the former group. Given the evident difficulties of keeping children safe in a custodial environment, a range of organisations called upon the government to exercise 'political leadership' by instigating a managed programme of releasing child detainees (Willow et al, 2020, p1). The government's response was barely adequate to the severity of the circumstances. Temporary release guidance, published in April 2020, applied to all prisoners but the exceptions, and the risk adverse nature of assessments, ensured that few children would benefit (Ministry of Justice, 2020). The Youth Custody Service acknowledged in May 2020 that the number of children 'in scope' was small and, in early June, it was confirmed that none had been released under the scheme (House of Commons Justice Committee, 2020).

Overtures were also made to the judiciary to refrain from imposing prison sentences on children 'at all costs' (Howard League for Penal Reform, 2020a). On this front, there is some evidence of potential success: between March and May 2020 , the population of the children's secure estate reduced from 737 to 614 , a decline of $17 \%$. It is not however clear whether this contraction is a consequence of more lenient sentencing or an artefact of a growing court backlog arising from the closure of more than half of the courts in England and Wales during lockdown (Dearden, 2020). Either way, it is apparent that for those children who remain within custodial institutions, the situation has taken on an even more dire quality than that which characterises the 'normal' pains of incarceration.

The standard prison regime - its shortcomings notwithstanding - has been 'paused" (Ministry of Justice / HM Prisons and Probation Service, 2020). While SCHs have managed to maintain 'an almost normal routine' eliciting 'really positive feedback from children about how staff are looking after them and the care they are receiving' (Common, 2020), YOIs and STCs have struggled to comply with guidance 
on social distancing (Children's Commissioner for England, 2020). Education has been severely restricted: in four out of the five YOIs, children's educational activities have been limited to the provision of worksheets in their cells; in the fifth, Parc YOI in Wales which is considerably smaller than the other establishments, children receive just two hours face-to-face teaching a day (HM Inspectorate of Prisons, 2020a). STCs have fared little better: Oakhill provides one hour face-to-face education per week; Rainsbrook has distributed individual education packs and has offered group sessions 'on the units'. In most establishments, communal meals have also been discontinued (Children's Commissioners, 2020, p6).

The inevitable corollary of these curbs is children spending more time in their cells with no social contact. In July 2020, HM Chief Inspector of Prisons reported that in YOls:

' nearly all children had been locked up for more than 22 hours every day since the start of the restrictions, which had been imposed some 15 weeks before our visit' (HM Inspectorate of Prisons, 2020a, p7).

Solitary confinement has accordingly become the norm: indeed it has received statutory authorisation. Amendments to the STC rules reduce the amount of time a child must be out of their room from 14 to 1.5 hours a day. As the rest of Britain gradually emerged from lockdown, the constraints on children in custody have remained in place and will do so for the foreseeable future: the revised regulations apply until March 2022 (Great Britain, 2020). In June 2020, Angus Mulready-Jones, lead prisons inspector for children and young adults, gave evidence to the Justice Committee that the administration of such additional 'pains', over an extended period, were clearly disproportionate.

'Was it acceptable on 23 March to shut down regimes... so that you could assess the situation and start delivering a service safely to children? Absolutely it was. Is it still acceptable 10 weeks down the line to be in a position where children across the estate are locked up in excess of 22 hours a day? No, that is not an acceptable position'(House of Commons Justice Committee, 2020, Q179).

Children in custody rely heavily on contact with the outside word (Day et al, 2020). Lockdown in prison has been accompanied by a complete cessation of personal and professional visits. Children in SCHs are entitled to free telephone calls to their families, but such calls are restricted in STCs and YOIs. While these latter establishments have all increased children's telephone credits, there appears to be no rationale for the considerable differences in the amounts given (HM Inspectorate of Prisons, 2020b; Children's Commissioner, 2020), let alone any justification for 
the requirement to pay in the first place. While in the community, as noted above, digital interactions can act to compensate, to some degree, for the lack of social contact, moves to enable video conferencing in custody have been slow and met with a low take-up, in part because children find the enforced presence of a member of staff inhibiting (HM Inspectorate of Prisons, 2020a). The consequent absence of familial support, is as one child has put it: 'the hardest thing I've gone through' (Children's Commissioner, 2020, p8).

Covid related constraints, on already impoverished regimes, have inevitably heightened the acute emotional strain on this group of extremely vulnerable children, eliciting increased concerns about the implications for their mental health in the longer term (Howard League for Penal Reform, 2020b). In this context, the inadequate access to mental health support available to children in normal times noted above - takes on a particularly disturbing aspect.

\section{Concluding thoughts}

The treatment of children in custody prior to the Covid 19 crisis provides conclusive testimony that the pains of imprisonment extend far beyond those associated with the restriction on liberty. They are inhumane and evidently unjustifiable on the basis of what children 'deserve'. While lockdown has curtailed the freedom of all, the repercussions for children deprived of their liberty have been far more brutal and difficult to align with any notion of justice or proportionality. The infliction of increased suffering has, furthermore, been chosen as the default response to extraordinary circumstances in preference to the alternative of allowing children to return to their locked-down communities. From the current author's perspective, the suspicion that this intensely vulnerable group of children are systemically constructed as being less deserving of consideration, and just deserts, than those from more advantaged backgrounds, is not easily dismissed. 


\section{References}

Ashworth, A (2017), 'Prisons, proportionality and recent penal history', in Modern Law Review 80(3): 473-478

Bateman, T (2016), The state of youth custody. London: National Association for Youth Justice

Bateman, T (2020), The state of youth justice: an overview of trends and developments. London: National Association for Youth Justice

Children's Commissioner for England (2020), Children in custody. London:

Children's Commissioner for England

Common, S (2020), Secure children's homes - helping the most vulnerable children. Blog posted 9 June 2020. Manchester: Ofsted, available at:

https://socialcareinspection.blog.gov.uk/2020/06/09/secure-childrens-homeshelping-the-most-vulnerable-children/

Day, AM, Bateman, T and Pitts, J (2020), Surviving incarceration: the pathways of looked after and non-looked after children into, through and out of custody. Luton: University of Bedfordshire

Dearden, L (2020), 'Court backlog rockets to more than half a million cases in England and Wales during coronavirus', The Guardian 20 June 2020.

End Child Imprisonment (2019) Principles and minimum expectations for children deprived of their liberty. London: End Child Imprisonment

Gooch, K (2016), 'A childhood cut short: child deaths in penal custody and the pains of child imprisonment', in The Howard Journal of Criminal Justice 55(3): 278-294

Great Britain (2020), The Secure Training Centre (Coronavirus) (Amendment) Rules 2020. SI 2020/664. London: The Stationery Office

HM Chief Inspector of Prisons (2019), Annual Report 2018-19. London: HMIP

HM Inspectorate of Prisons (2019), Separation of children in young offender institutions: a thematic review. London: HM Inspectorate of Prisons 
HM Inspectorate of Prisons (2020a), Report on short scrutiny visits to Young offender institutions holding children: 7 July 2020. London: HM Inspectorate of Prisons

HM Inspectorate of Prisons (2020b), Report on short scrutiny visits to Young offender institutions holding children: 21 April 2020. London: HM Inspectorate of Prisons

Howard League for Penal Reform (2020a), Judicial decision making concerning children in the criminal courts in light of the Coronavirus pandemic. Letter to Mr Justice William Davis, District Judge Naomi Redhouse, Sian Jones, and Linda Logan, 26 March 2020. London: Howard League, available at:

https://howardleague.org/wp-content/uploads/2020/03/Letter-on-judicialdecision-making-concerning-children-in-the-criminal-courts-in-light-of-thecoronavirus-pandemic.pdf

Howard League for Penal Reform (2020b), Children in prison during the Covid-19 pandemic. London: Howard League

House of Commons Justice Committee (2020), Coronavirus (Covid-19): The impact on prison, probation and court systems: oral evidence, 2 June 2020. London: House of Commons

Ignatieff, M (1989), A just measure of pain: the penitentiary in the Industrial Revolution 1750-1850. New York: Pantheon

Independent Advisory Panel on Deaths in Custody (2020), 'Keep talking, stay safe'. $A$ rapid review of prisoners' experience under Covid-19. London: Independent Advisory Panel on Deaths in Custody

Jacobson, J, Bhardwa, B, Gyateng, T, Hunter, G and Hough, M (2010) Punishing disadvantage: a profile of children in custody. London: Prison Reform Trust

Jay, A, Evans, M, Frank, I and Sharpling, D (2019), Sexual abuse of children in custodial institutions: 2009-2017. London: Independent Inquiry into Child Sexual Abuse

Kingston, S and Webster, C (2016), 'The most 'undeserving' of all? How poverty drives young men to victimisation and crime' in Journal of Poverty and Social Justice 23(3), 215-227 
Lacey, N and Pickard, H (2015), 'The chimera of proportionality: institutionalising limits on punishment in contemporary social and political systems' in Modern Law Review 78(2):216-240

Liebling, A (2011), 'Moral performance, inhumane treatment and prison pain' in Punishment and Society 13(5):530-550

Little, R (2020a), Solitary confinement. Blog posted 7 May 2020. London: National Association for Youth Justice, available at: https://thenayj.org.uk/blog-solitaryconfinement/

Little, R (2020b), 'Paying the price: consequences for children's education in prison in a market society', in International Journal of Educational Development 27, published online June 2020

McAlister, S and Carr, N (2014), 'Experiences of youth justice: youth justice discourses and their multiple effects' in Youth Justice 14(3):251-254

Ministry of Justice (2016), The government response to Charlie Taylor's Review of the youth justice system. London: Ministry of Justice

Ministry of Justice (2020), End of custody temporary release. London: Ministry of Justice

Ministry of Justice / Youth Justice Board (2020a), Youth justice statistics 2018/19: England and Wales. London: Ministry of Justice

Ministry of Justice / Youth Justice Board (2020b), Assessing the needs of sentenced children in the youth justice system 2018/19. London: Youth Justice Board

Orben, A, Tomova, L and Blakemore, SJ (2020), 'The effects of social deprivation on adolescent development and mental health' in The Lancet: child and adolescent health 2020(4), pp634-40

Sentencing Council (2017), Sentencing children and young people: overarching principles and offence specific guidelines for sexual offences and robbery: definitive guideline. London: Sentencing Council

Standing Committee for Youth Justice (2020), Ensuring custody is the last resort for children in England and Wales. London: Standing Committee for Youth Justice 
Sykes, GM (1958/2007), The society of captives: a study of a maximum security prison. Princeton, NJ: Princeton University Press

Taflan, P and Jalil, R (2020), Children in custody 2018-19: an analysis of 12-18year-olds' perceptions of their experiences in secure training centres and young offender institutions. London: HM Inspectorate of Prisons

Taylor, C (2016), Review of the youth justice system in England and Wales. London: Ministry of Justice

Taylor, C (2020), A review of the use of pain-inducing techniques in the youth secure estate. London: Ministry of Justice

United Nations (1989), Convention on the Rights of the Child. Geneva: United Nations

United Nations (2015), United Nations Standard Minimum Rules for the Treatment of Prisoners (the Mandela Rules). Geneva: United Nations,

Webster, C (2015), '“Race”, crime and youth justice' in Goldson, B and Muncie, J (eds) Youth crime and justice, $2^{\text {nd }}$ edition. London: Sage, 31-48

Willow, C and nine others (2020), Coronavirus (Covid 19) - children in prison. Letter to Robert Buckland, Lord Chancellor and Secretary of State for Justice, 18 March 2020, available at: https://thenayj.org.uk/cmsAdmin/uploads/coronavirus-andchild-prisons-joint-letter-to-sos-justice-18mar2020.pdf

Wood, A, Bailey, S and Butler, R (2017), Findings and recommendations of the Youth Custody Improvement Board. London: Youth Custody Improvement Board

Yates, J (2010), 'Structural disadvantage, youth, class, crime and poverty' in Taylor, W, Earle, R and Hester, R (eds) Youth Justice handbook: theory, policy and practice. Cullompton: Willan, 5-22

Youth Custody Service (2020), Monthly Youth Custody Report - May 2020. London: Ministry of Justice 